\title{
EFFECT OF WORKING PRESSURE AT DIFFERENT SPRAY NOZZLES ON DRIFT QUANTIFICATION IN WIND TUNNEL
}

\section{MARCO A. GANDOLFO ${ }^{1}$, FERNANDO K. CARVALHO ${ }^{2}$, RODOLFO G. CHECHETTO ${ }^{3}$, ULISSES D. GANDOLFO ${ }^{4}$, EDER D. DE MORAES ${ }^{5}$}

\begin{abstract}
Each year, there is an increase in pesticide consumption and in its importance of use in the large-scale agricultural production, being fundamental the knowledge of application technology to the activity success. The objective of the present study was to evaluate the influence of working pressure on the drift generated by different spray nozzles, assessed in wind tunnel. The treatments were composed of two spray nozzles AXI 110015 and AXI 11002 with pressure levels of 276 and $414 \mathrm{kPa}$. The spray solution was composed by water and $\mathrm{NaCl}$ at $10 \%$. The applications were conducted at wind speed of $2.0 \mathrm{~m} \mathrm{~s}^{-1}$, being the drift collected at $5.0 ; 10.0$ and $15.0 \mathrm{~m}$ away from the spray boom and at heights of $0.2 ; 0.4 ; 0.6 ; 0.8$ e $1.0 \mathrm{~m}$ from the tunnel floor. To both spray nozzles, the greatest drift was collected at the smallest distance to the spray-boom and at the lowest height. The AXI 11002 nozzle gave a smaller drift relative to the AXI 110015 nozzle for the two tested pressures and for all the collection points. Regardless of the nozzle, a rise in the working pressure increases the spray drift percentage at all distances in the wind tunnel.
\end{abstract}

KEY-WORDS: Application technology, pesticides, environmental contamination.

\section{EFEITO DA PRESSÃO DE TRABALHO EM DIFERENTES PONTAS DE PULVERIZAÇÃO NA QUANTIFICAÇÃO DA DERIVA EM TÚNEL DE VENTO}

RESUMO: A cada ano, há um aumento no consumo e na importância do uso de agrotóxicos na produção agrícola em alta escala, sendo fundamental o conhecimento da tecnologia de aplicação para o sucesso da atividade. O objetivo deste trabalho foi avaliar a influência da pressão de trabalho sobre a deriva gerada por diferentes pontas de pulverização, avaliada em túnel de vento. Os tratamentos foram compostos por duas pontas de pulverização: AXI 110015 e AXI 11002, nas pressões de 276 e $414 \mathrm{kPa}$. A calda de pulverização foi composta por água e $\mathrm{NaCl}$ a $10 \%$. As aplicações foram realizadas com velocidade de vento de $2,0 \mathrm{~m} \mathrm{~s}^{-1}$, sendo a deriva coletada a 5,0; 10,0 e 15,0 m de distância da barra de pulverização e nas alturas de 0,2;0,4;0,6;0,8 e 1,0 m em relação ao piso do túnel. Para as duas pontas de pulverização, a maior deriva coletada ocorreu na menor distância em relação à barra de pulverização e na menor altura em relação ao piso do túnel. O modelo de ponta AXI 11002 apresenta menor porcentagem de deriva coletada em relação ao modelo AXI 110015, para as duas pressões testadas e em todos os pontos de coleta. Independentemente da ponta, o aumento da pressão de trabalho aumenta a porcentagem de deriva em todas as distâncias de coleta realizadas no túnel de vento.

PALAVRAS-CHAVE: Tecnologia de aplicação, agrotóxicos, contaminação ambiental.

\footnotetext{
${ }^{1}$ Eng $^{\mathrm{o}}$ Agrônomo, Prof. Doutor, Depto. de Engenharia e Desenvolvimento Agrário, UENP, gandolfo@uenp.edu.br

${ }^{2}$ Eng $^{\circ}$ Agrônomo, Doutorando, Departamento de Engenharia Rural, UNESP/Botucatu - SP, fernandokassis@ @otmail.com

${ }^{3}$ Eng $^{\mathrm{o}}$ Agrônomo, Doutorando, Departamento de Engenharia Rural, UNESP/Botucatu - SP, rgchechetto@ hotmail.com

${ }^{4}$ Eng ${ }^{\circ}$ Agrônomo, Mestrando, Departamento de Engenharia Rural, UNESP/Botucatu - SP, ulissesgandolfo@ hotmail.com

${ }^{5}$ Eng $^{\circ}$ Agrônomo, Mestrando, Departamento de Engenharia e Desenvolvimento Agrário, UENP, ederdiasdemoraes@gmail.com

Recebido pelo Conselho Editorial em: 16-2-2012

Aprovado pelo Conselho Editorial em: 5-9-2013
} 


\section{INTRODUTION}

The use of pesticides has become essential to the large-scale agricultural production; however, they pose risks to the environment due to several factors, among them, the spray drift. According to COSTA et al. (2007), despite being increasingly required the correct and careful use of pesticides, farmers show lack of knowledge of the application technology. According to CUNHA (2008), it is common to give great importance to the pesticides and less to the applied application technology.

Another factor to be considered is the biological target, which may require different application technologies, among them, the droplet spectrum variation, which depends on the product mode of action and on the culture vegetative development, however, the environmental characteristics must be considered in order to avoid spray drift and to ensure the action of the product.

One of the solutions found by some countries to avoid problems resulting from environmental contamination caused by the drift is the creation of security zones, known as "buffer zones" (CUNHA, 2008). This term refers to a vegetation strip exempt of pesticide application, serving to protect sensitive areas, such as water bodies. According to CUNHA et al. (2010), there is no indicative standard value of droplets subject to drift risk or to a safe application. And as the extension of this strip is variable and depends on application conditions, studies that simulate the horizontal distance that a droplet can travel under several application conditions serve to settle the correct extension of these security zones.

One important tool to simulate the results of the drift in field conditions are the experiments realized in wind tunnel (PHILLIPS \& MILLER, 1999). Wind tunnel enables a more secure analysis formed by different spray nozzles and by different products under wind controlled conditions.

The pesticide application success depends on the use of spray nozzles of uniform lateral distribution and homogeneous droplet spectrum, being that the spray nozzle role is to fragment and to distribute the liquid into droplets. In the market, there are nozzles that present a pre-orifice that try to unite the benefits of drop penetration in foliar mass with a medium droplet spectrum, being less prone to drift (CUNHA et al., 2008).

Despite of the importance attributed to spray nozzle characteristics, in the final result of an application, still there is uncertainty about its real effect (BOLLER \& MARCHRY, 2007; FAGGION \& ANTUNIASSI, 2010). The increase in pressure is a common and recommended practice to raise the application tax and, consequently, to extend the drop coverage over the leaves, being that many times, farmers use the same type of nozzle to several activities, but although this is an effective way to increase the number of the produced droplets, an increase in pressure reduces the average diameter of them, making them prone to drift effects and evaporation losses (CAMARA et al., 2008; VIANA et al., 2010).

This study aims to evaluate the influence of working pressures on different standard flat spray nozzles on drift quantification in applications conducted in wind tunnel.

\section{MATERIAL AND METHODS}

This study was conducted in the "Núcleo de Investigação em Tecnologia de Aplicação de Agroquímicos e Máquinas Agrícolas" - NITEC, Luiz Meneghel Campus - CLM, in the State University of the North of Paraná - UENP, Bandeirantes, State of Paraná.

The utilized treatments are presented in Table 1. According to the standard ASAE S572 and information provided by the manufacturer Agricultural Machines Jacto S/A (Máquinas Agrícolas Jacto S/A), the utilized spray nozzles form small droplets (JACTO, 2013). The experiment included four treatments (combination of factors), two nozzles and two working pressures with three repetitions. 
TABLE 1. Description of treatments.

\begin{tabular}{ccccc}
\hline Treatment & Spray nozzle type & Nozzle model & $\begin{array}{c}\text { Recomended pressure } \\
\text { Minimum and } \\
\text { maximum (kPa) }\end{array}$ & $\begin{array}{c}\text { Working } \\
\text { pressure (kPa) }\end{array}$ \\
\hline 1 & Standard flat nozzle & AXI 110015 & $103-414$ & 276 \\
2 & Standard flat nozzle & AXI 110015 & $103-414$ & 414 \\
3 & Standard flat nozzle & AXI 11002 & $103-414$ & 276 \\
4 & Standard flat nozzle & AXI 11002 & $103-414$ & 414 \\
\hline
\end{tabular}

The test was conducted in wind tunnel with open loop, built in masonry, with square section of $2 \mathrm{~m}$ and $20 \mathrm{~m}$ of length. The ventilation was promoted by an axial fan of double helix, of $0.9 \mathrm{~m}$ of diameter, activated by a power takeoff (TDP) of a $65 \mathrm{~kW}$ engine power truck.

The spray system was composed by a reservoir of $50 \mathrm{~L}$ of capacity, where the solution was stored and pressured by a hydraulic pump of piston JP 42 model manufactured by Agricultural Machines Jacto S/A (Máquinas Agrícolas Jacto S/A). The system also had a spray boom, installed at the initial third of the tunnel, $2.0 \mathrm{~m}$ away from the hive and at height of $0.6 \mathrm{~m}$ from the tunnel floor, provided with three nozzles spaced apart every $0.5 \mathrm{~m}$, anti-drip valves and nozzles, of caps, sealing rings and filters (mesh number 80 for the nozzle AXI 110015 model and mesh number 50 for the nozzle AXI 11002 model). The system also presented an analogue manometer Wika brand with maximum scale of $828 \mathrm{kPa}$ (120 psi) and divisions of $35 \mathrm{kPa}$ (5 psi). The control of the solution flow was carried out manually through a mechanical valve and the utilized mechanical pressure regulator was the VAR model, manufactured by Jacto Agricultural Machines S/A (Máquinas Agrícolas Jacto S/A), also utilized to switch the system on and off.

The drift collections were made at 5.0; 10.0 and $15.0 \mathrm{~m}$ of distance from the spray boom and at $0.2 ; 0.4 ; 0.6 ; 0.8$ and $1.0 \mathrm{~m}$ of height from the tunnel floor. Polyethylene wires of $2 \mathrm{~mm}$ of diameter and $300 \mathrm{~mm}$ of length were utilized, fixed in metal support of rectangular shape and transversely positioned in relation to the air flow, in the respective cited heights and distances. In order to be placed and removed from the test section, the supports of the wires were fixed in vertical drawers that moved over metal rails in the tunnel floor in a way that, when closed, they positioned the collectors in the center of the tunnel and also closed the lateral side of the tunnel avoiding the ventilated air output.

The stipulated air speed was $2.0 \mathrm{~m} \mathrm{~s}^{-1}$, being measured before the application of each treatment, at five meters of distance from the spray boom and at one meter of height from the tunnel floor. The variations of the wind speed for adjustment were obtained varying the power take-off rotation of the truck connected to the ventilator by the variation of the engine rotation being the measures of the wind speed made by blower anemometer A892160 model, Extech brand. Temperature and relative humidity of the air readings were made at the same place of the anemometer installation, by a digital thermo-hygrometer, Minipa brand MT-241 model, with a precision of $0.1^{\circ} \mathrm{C}$ of temperature and $1 \%$ of relative humidity of the air. All the applications were conducted in ideal boundary conditions to spraying, over $55 \%$ of relative humidity of the air and under $30^{\circ} \mathrm{C}$ of temperature.

In order to determine the sprayed liquid drift, a method of analysis of electrical conductivity determination, sodium chloride marker $(\mathrm{NaCl})$, and mass concentration of $10 \%$ (ABI SAAB, 1996) was utilized, which was recovered by a washing solution of the collector wires with deionized and distilled water.

The spraying was performed for three minutes each and right after that a period of 5 minutes was allowed for stabilization of the suspended particles inside the wind tunnel. The collected wires were individually placed into PVC tubes with lids, of $0.5 \mathrm{~m}$ of length and numbered accordingly to the distance and height of the collection. 
In each PVC tube, $50 \mathrm{ml}$ of deionized water was added to washing. The deionized dosage was made by a precision disperser. The tube stir was manually performed for 20 seconds. After this procedure the water from the washing of the tubes was placed into a plastic recipient with lid, with the same numbering of the PVC tube, where the electrodes of the digital conductivimeter CD 203 and Phtek brand of $1.0 \mu \mathrm{S}$ precision and maximum scale of $1999 \mu \mathrm{S}$ (micro-Siemens), were immersed to measure the electrical conductivity. This reading served as a reference to the volume of collected liquid per each wire during the spraying, being that several measurements of electrical conductivity in different $\mathrm{NaCl}$ concentrations, establishing a standard curve between the marker and its electrical conductivity.

A mathematical equation was determined from the curve and related the electrical conductivity of the solution to its tracer quantity. The insertion of the electrical conductivity values obtained from the wire washing resulted in the quantity of the marker collected in the evaluations. From this value and the quantity of the sprayed marker during the collection, the drift percentage collected for each treatment was calculated.

To correct a possible electrical conductivity without use in the target, evaluations were conducted in ten tubes with ten wires and the average value of the ten readings was subtracted from the values obtained from the collections. The results from the treatments were compared by the Confidence Interval for the Difference between the Means, at $5 \%$ of probability ( $\mathrm{IC}_{95 \%}$ ).

\section{RESULTS AND DISCUSSION}

It is noted from figure 1 that the standard flat spray nozzle AXI 110015 model presents a collected drift similar to the one from AXI 11002 model for the same evaluated distances and heights under pressure of $276 \mathrm{kPa}$. However, a tendency of greater collected drift can be observed for the nozzle of smaller flow. For the two nozzles, the greatest collected drift occurred for the smallest distance in relation to the spray nozzles and for the lowest height in relation to the wind tunnel floor. At the smallest distances and heights, the drift of the 110015 nozzle was $11.9 \%$ greater in relation to the AXI 11002 model, however, without presenting any statistical differences. The smallest drift percentage occurred for the distance of 15.0 meters in relation to the spray boom and for the height of $1.0 \mathrm{~m}$ in relation to the tunnel floor, at this point the collected drift was on average 46.0\% lower for the flat fan nozzle AXI 11002 model in relation to the 110015 model, presenting statistical difference between them.

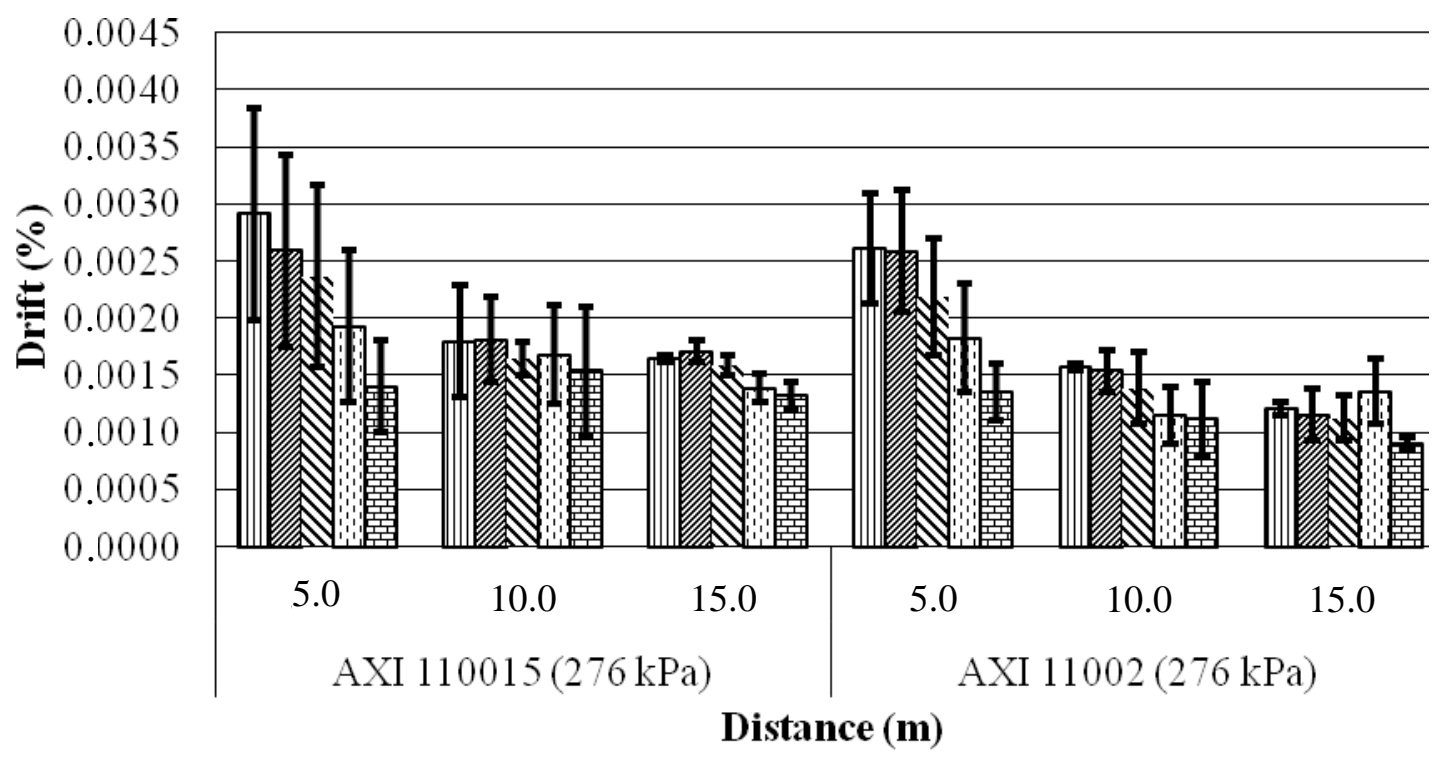

$$
\mathbf{\square} 0.2 \mathrm{~m} \quad 0.4 \mathrm{~m} \quad \mathbf{2} 0.6 \mathrm{~m} \quad \mathbf{\square} 0.8 \mathrm{~m} \quad \mathbf{\Delta} 1.0 \mathrm{~m}
$$

FIGURE 1. Drift percentage (mean confidence interval at 95\%) at different heights from the wind tunnel floor and distances in relation to the different nozzles at $276 \mathrm{kPa}$ of pressure. 
In the MOREIRA JÚNIOR (2009) study, conducted for the validation of a wind tunnel with the standard flat spray nozzles, the found drift values follow the same pattern from the ones found in the present study, being that the lowest drift were found at the biggest distances and heights in relation to the spray boom and tunnel floor, respectively. Similar results of this pattern were found in validated tunnels, in studies conducted by COSTA (2006), OLIVEIRA (2011) and CHECHETTO et al. (2013).

In figure 2, the drift percentages are presented for the standard flat spray nozzles AXI 110015 and AXI 11002 under the pressure of $414 \mathrm{kPa}$. A similar pattern is found for the working pressure of $276 \mathrm{kPa}$; however, for the 110015 nozzle the greatest drift was found at the distance of 5.0 meters from the spray nozzle and at $0.4 \mathrm{~m}$ from the tunnel floor, not showing difference between the heights of $0.2 ; 0.6$ and $0.8 \mathrm{~m}$ at the same evaluated distance.

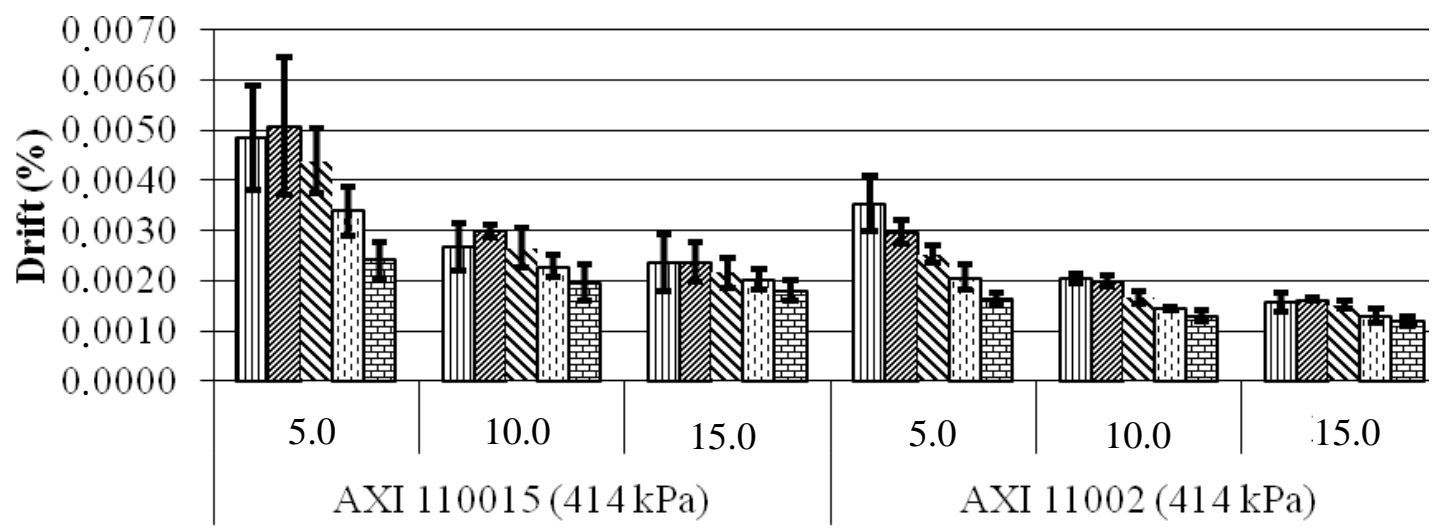

Distance (m)

$$
\mathbb{\square} 0.2 \mathrm{~m} \quad 0.4 \mathrm{~m} \quad \mathbf{*} 0.6 \mathrm{~m} \quad \boldsymbol{\square} 0.8 \mathrm{~m} \quad \mathbf{\square} 1.0 \mathrm{~m}
$$

FIGURE 2. Drift percentage (mean confidence interval at 95\%) at different heights from the floor of the wind tunnel, and distances in relation to the different nozzles under pressure of $414 \mathrm{kPa}$.

The AXI 11002 nozzle, at the distance of 5.0 meters, showed a reduction of the drift percentage of $36.9 ; 71.0 ; 72.8 ; 63.8$ and $47.6 \%$ for the heights of $0.2 ; 0.4 ; 0.6 ; 0.8$ and $1.0 \mathrm{~m}$, respectively, in relation to the same distance for the AXI 110015 nozzle, being statistically significant the reductions at the distances of $0.4 ; 0.6 ; 0.8$ and $1.0 \mathrm{~m}$. This pattern of drift reduction in favor of the 11002 nozzle is maintained in the order of $30.7 ; 50.0 ; 58.3 ; 59.0$ and $49.6 \%$ at the distance of 10.0 meters and $50.0 ; 45.4 ; 42.8 ; 55.0$ and $50.8 \%$ for the distance of 15.0 meters in relation to the 110015 spray nozzles, presenting a statistically significant difference for the last two distances in drift reduction.

According to the manufacturer, the nozzle AXI 110015 and AXI 11002 present a spectrum of small droplets, of 115 and $119 \mu \mathrm{m}$ for the pressure of $414 \mathrm{kPa}$, respectively. In accordance with observations from this study, ANTUNIASSI (2009) by analyzing spray nozzles, asserts that the higher is the percentage of small droplets that compounds the spectrum of produced droplets, certainly the risk of drift will be higher, being this concept utilized to underlie a new classification of spray nozzles. However, CUNHA et al. (2010) stated that there is no standard value for the droplets below $100 \mu \mathrm{m}$ that indicates a real drift risk.

Another considered factor is that an increase in pressure from 276 to $414 \mathrm{kPa}$ rises the flow from 0.57 to $0.74 \mathrm{~L} \mathrm{~min}^{-1}$ for the AXI 110015 model and from 0.80 to $0.99 \mathrm{~L} \mathrm{~min}^{-1}$ for the nozzle AXI 11002 model, and with that there is a longstanding effect that an increase in pressure results in a rise in flow, consequently producing a reduction in the size of the sprayed droplets, which is clearly reflected in the increase of the drift as previously shown in the figures. According to 
CAMARA et al. (2008), by testing a standard flat fan spray nozzle 11003 model, reported that an increase in pressure from 200 to $400 \mathrm{kPa}$ reduced the average diameter of the sprayed droplets in $16.4 \%$, turning them into more susceptible to the drift effects and evaporation losses.

The figure 3 is presented in order to compare the models of spray nozzles and the utilized pressures, where is clearly noted that the nozzle AXI 11002 model presents a smaller drift percentage in relation to the AXI 110015 model for the two tested pressures. By varying the pressure inside the same model, it is possible to notice a considerable increase in the drift percentage at pressure of $414 \mathrm{kPa}$.

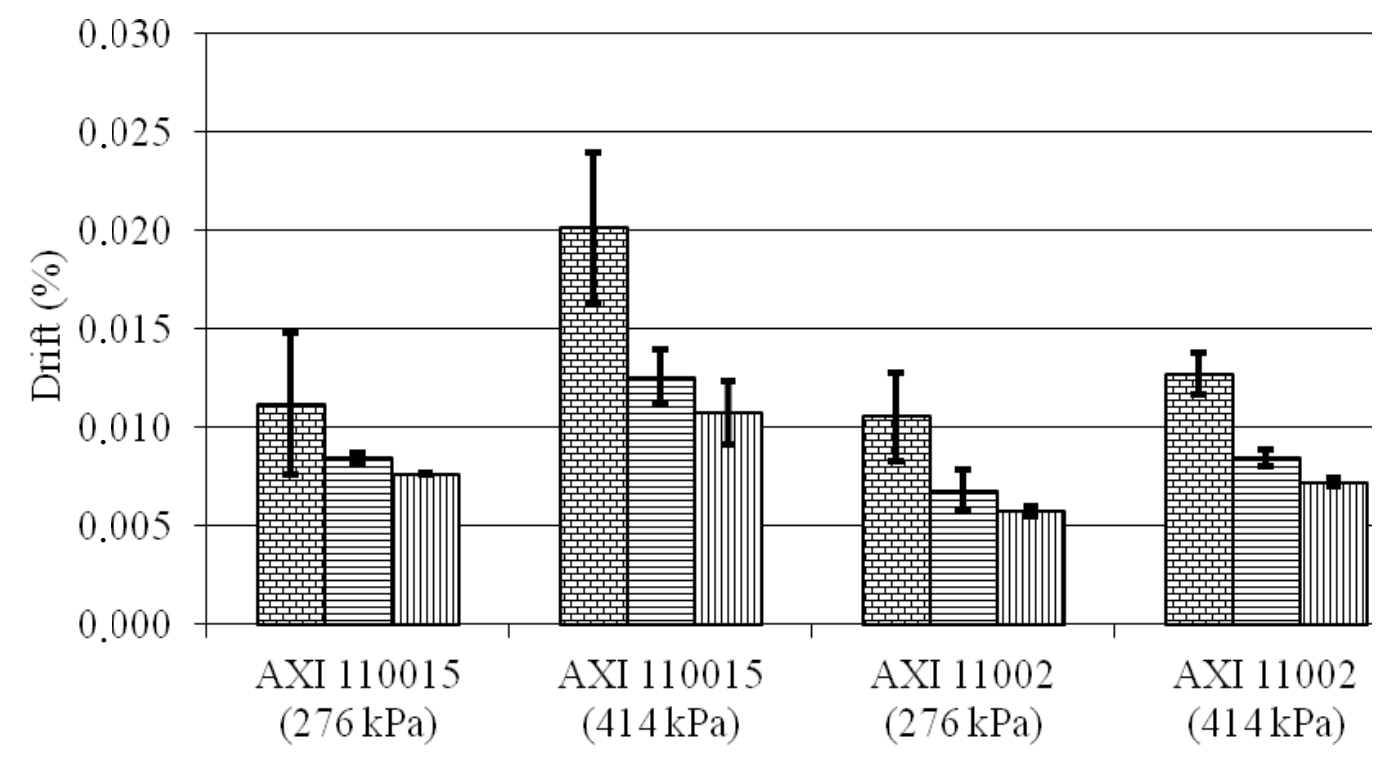

Spray nozzle models

\section{因 $5.0 \mathrm{~m}$ 目 $10.0 \mathrm{~m} \mathrm{\square} 15.0 \mathrm{~m}$}

FIGURE 3. Drift percentage (mean confidence interval at 95\%) at different distances in relation to the different nozzles at the used pressures of 276 and $414 \mathrm{kPa}$.

Under the pressure of $276 \mathrm{kPa}$, there was no statistical difference in drift percentage between the different collections for the AXI 110015 model. For this model of nozzle, a rise in pressure resulted in an increase of $79.5 \%$ of the drift percentage for the 5.0 meters of distance from the spray boom. According to FERNANDES et al. (2007), a rise in pressure reduces the medium volumetric diameter (MVD) of the sprayed droplets that directly increases the risk of drift. For the distances of 10.0 and 15.0 meters, this percentage was of 48.6 and $40.4 \%$ respectively, presenting significant difference between them under the pressure of $276 \mathrm{kPa}$.

The increase in the working pressure resulted in a rise of $20.7 ; 24.8$ and $25.9 \%$ in the collected drift respectively between the distances of 5.0; 10.0; and 15.0 meters from the spray boom for the nozzle model AXI 11002. The rise in pressure also caused a significant difference of the collected drift in all the collection distances, being that there was no significant difference between the distances of 10 and 15 meters for the lowest pressure. However, for the AXI 110015 model, the increase in the collected drift with the rise in pressure was of 81.8; 50.0 and $57.1 \%$ for the distances of 5.0; 10.0 and 15.0 meters, respectively.

Caused by a rise in pressure, these numbers indicate an increase in the collected drift of at least the double for the lowest flow in relation to the highest flow. In accordance to this fact, it can be admitted that an increase in the working pressure as a way to obtain greater flow from the nozzle, although considered a routine action, as observed by CAMARA et al. (2008) and VIANA et al. (2010), it must be considered less safe to the drift risks than the use of nozzles of higher flow as 
they offer similar flows at lower pressures.

COSTA (2006), tested a standard flat nozzle 11002 at pressures of 150 and $300 \mathrm{kPa}$ and the generated spray drift was greater for the highest pressure at all tested distances in relation to the spray nozzle, a result similar to the one found in the present study. The same author observed a smaller drift for the nozzles of higher droplet spectrum, generating basis that the greater the size of the droplet, the smaller the spray drift, a pattern that was also found in the present study.

\section{CONCLUSIONS}

The nozzle AXI 110015 generates a higher percentage of spray drift in relation to the AXI 11002, regardless of the working pressure used

The rise in pressure increases the spray drift percentage at all distances in the wind tunnel for the two tested nozzles, being this increase higher for the nozzle AXI 110015 in relation to AXI 11002.

The increase in the sprayer rate of application by the rise in the spray nozzle flow associated to the smaller risk of spray drift is due to the use of greater flow nozzles rather than the rise in the working pressure.

\section{REFERENCES}

ABI SAAB, O. J. G. Avaliação de um sistema de aplicação de defensivos utilizados em videiras no município de Londrina - PR. 1996. 65 f. Dissertação (Mestrado em Energia na Agricultura) Faculdade de Ciências Agronômicas, Universidade Estadual Paulista, Botucatu, 1996.

ANTUNIASSI, U. R. Conceitos básicos da tecnologia de aplicação de defensivos para a cultura da soja. Boletim de Pesquisa de Soja, Rondonópolis, v. 13, p. 299-317, 2009.

BOLLER, W.; MACHRY, M. Efeito da pressão de trabalho e de pontas de pulverização sobre a eficiência de herbicidas de contato em soja. Engenharia Agrícola, Jaboticabal, v. 27, n. 3, p. 722727, set/dez. 2007.

CAMARA, F. T.; SANTOS, J. L.; SILVA, E. A.; FERREIRA, M. C. Distribuição volumétrica e espectro de gotas de bicos hidráulicos de jato plano de faixa expandida XR11003. Engenharia Agrícola, Jaboticabal, v. 28, n. 4, p.740-749, 2008.

CHECHETTO, R. G.; ANTUNIASSI, U. R.; MOTA, A. A. B.; CARVALHO, F. K.; SILVA, A. C. A.; VILELA, C. M. Influência de pontas de pulverização e adjuvantes no potencial de redução de deriva em túnel de vento. Semina: Ciências Agrárias, Londrina, v. 34, n. 1, p. 37-46, jan./fev. 2013.

COSTA, A. G. F. Determinação da deriva da mistura 2,4-D e glyphosate com diferentes pontas de pulverização e adjuvantes. $2006.94 \mathrm{f}$. Tese (Doutorado em Agronomia/Agricultura) - Faculdade de Ciências Agronômicas, Universidade Estadual Paulista, Botucatu, 2006.

COSTA, A. G. F.; VELINI, E. D.; NEGRISOLI, E.; CARBONARI, C. A.; ROSSI, C. V. S.; CORRÊA, M. R.; SILVA, F. M. L. Efeito da intensidade do vento, da pressão e de pontas de pulverização na deriva de aplicações de herbicidas em pré-emergência. Planta Daninha, Viçosa, MG, v. 25, n. 1, p. 203-210, jan./mar., 2007.

CUNHA, J. P. A. R.; BUENO, M. R.; FERREIRA, M. C. Espectro de gotas de pontas de pulverização com adjuvantes de uso agrícola. Planta Daninha, Viçosa, MG, v. 28, p. 1153-1158, 2010. Numero Especial.

CUNHA, J. P. A. R. Simulação da deriva de agrotóxicos em diferentes condições de pulverização. Ciência e Agrotecnologia, Lavras, v. 32, n. 5, p. 1616-1621, set./out. 2008.

CUNHA, J. P. A. R.; MOURA, E. A. C.; SILVA JÚNIOR, J. L.; ZAGO, F. A.; JULIATTI, F. C. Efeito de pontas de pulverização no controle químico da ferrugem da soja. Engenharia Agrícola, 
Jaboticabal, v. 28, n. 2, p. 283-291, abr./jun. 2008.

FAGGION, F.; ANTUNIASSI, U. R. Desempenho de pontas de pulverização quanto a indução de ar nas gotas. Energia na Agricultura, Botucatu, v. 25, n. 4, p. 72-82, 2010.

FERNANDES, A. P.; PARREIRA, R. S.; FERREIRA, M. C.; ROMANI, G. N. Caracterização do perfil de deposição e do diâmetro de gotas e otimização do espaçamento entre bicos na barra de pulverização. EngenhariaAgrícola, Jaboticabal, v. 27, n. 3, p. 728-733, set./dez. 2007.

JACTO. Máquinas Agrícolas Jacto S/A - Tecnologia ao seu alcance. Disponível em: < http://www.jacto.com.br/pt/produto/detalhes/73/axi> Acesso em: 6 maio 2013.

MOREIRA JUNIOR, O. Construção e validação de um túnel de vento para ensaios de estimativa de deriva em pulverizações agrícolas. 2009. 72f. Tese (Doutorado em agronomia/ Energia na Agricultura)- Faculdade de Ciências Agronômicas, Universidade Estadual Paulista, Botucatu, 2009.

OLIVEIRA, R. B. Caracterização funcional de adjuvantes em soluções aquosas. 2011. 134 f. Tese (Doutorado em Agronomia/Energia na Agricultura)- Faculdade de Ciências Agronômicas, Universidade Estadual Paulista, Botucatu, 2011.

PHILLIPS, J. C.; MILLER' P. C. H. Field and wind tunnel measurements of the airborne spray volume downwind of single flat-fan nozzles. Journal of Agricultural Engineering Research, London, v. 72, n. 2, p. 161-170, 1999.

VIANA, R.G.; FERREIRA, L. R; FERREIRA, M.C.; TEIXEIRA, M. M; ROSELL, J. R.; TUFFI SANTOS, L. D.; MACHADO, A. F. L. Distribuição volumétrica e espectro de gotas de pontas de pulverização de baixa deriva. Planta Daninha, Viçosa, MG, v. 28, n. 2, p. 439-446, abr/jun. 2010. 